\title{
皮下膿瘍を形成した前頭洞炎例
}

一冠状切開法に上る根治例一

\author{
萩森 伸一・牧本一男・伊藤 尚 \\ 中小路澄子・野井理・高橋 宏明
}

\section{Frontal Sinusitis and Abscess}

\author{
Shin-ichi Haginomori, Kazuo Makimoto, Takashi Ito, \\ Sumiko Nakakoji, Osamu Noi and Hiroaki Takahashi \\ (Osaka Medical College)
}

\begin{abstract}
A 27-year-old male complaining of anterior frontal swelling and pain was sent to our hospital for further examination and treatment. Examinations, including X-ray, CTscan, MRI, led to a diagnosis of frontal sinusitis with bone defect of the anterior wall and a fistula between the frontal sinus and the skin. After radical maxilloethmoidectomy, an extranasal frontal sinus operation employing a coronal incision was performed under general anesthesia. A bone defect was found in the medio-superior portion of the left frontal sinus. The defect connected with the fistula to the frontal skin as an extension of the frontal sinus lesion. After complete removal of the inner wall lesions in the frontal sinus and nasofrontal duct, the latter was plugged with autogenous iliac bone grafts. Then autogenous abdominal fat was implanted into the frontal sinus. The anterior wall of the frontal sinus was reconstructed with an iliac bone graft. During the 34 months since surgery, he has had no recurrent infection and no cosmetic or functional problem. In conclusion, frontal sinus surgery via a coronal incision approach is feasible when a wide surgical field with direct visualization of the frontal sinus is required, and it can produce satisfactory results.
\end{abstract}

Key words : coronal incision, frontal sinusitis, autogenous abdominal fat

はじめに

本邦に捈いて前頭洞炎に対する根本手術はキリアン氏 法による眉毛内切開が多く用いられているが，前頭骨で の病巣が広範となっている場合は術野が大きく確保し難 く, 病巣の処理が不十分になることがある. それに対し て冠状切開は頭皮部に切開線を扣き, 皮弁を下方へ大き く翻転するため病巣部を充分に露出できるという利点が ある. 今回, 我々は保存的治療に抵抗した慢性前頭洞炎 による前額部皮下膿瘍症例に対し冠状切開による前頭洞 根本手術を施行し, 良好な結果が得られたので若干の考 察を加えて報告する.

\section{症例}

患者 : 27歳, 男性.

主訴：前額部の疼痛および腫脹.

既往歴 : 脊椎側弯症.

家族歴：父親に慢性副鼻腔炎の既往.

現病歴 : 平成 2 年 12 月下旬, 感冒症状ののち前額左側 に疼痛を自覚し，近医内科受診，感冒との診断を受け抗 生剂执よび消炎鎮痛剂等の投薬を受けて一旦症状は軽快 した。しかし平成 3 年 1 月中旬に前額やや左側の腫脹を 来し疼痛も増したため, 近医脳神経外科を受診, 前額部 皮下膿瘍の診断にて腫脹部位の切開排膿が施行された。 
以後計 4 回同様の処置を受けたが前額部腫脹は軽快せず 再発をくり返した，鼻副鼻腔疾患の関連も考它られ，同 年 2 月下旬, 近医耳鼻咽喉科に紹介され受診した。乞の 際単純 X線撮影，CT 検査にて両側上顎洞および篩骨洞， 左前頭洞に粘膜肥厚が，また前額部の腫脹部位に部分的 な骨欠損が認められた. 以上の結果から左前頭洞炎に起 因与る皮下膿瘍が疑われ，精査，加療目的にて同年 3 月 19日, 本学耳鼻咽喉科を紹介され，4月1日入院となっ た。

入院時所見：左右眉毛の中間点より約 $30 \mathrm{~mm}$ 上方に 直径 $3 \mathrm{~mm}$ の皮膚瘦孔を認めた。皮膚瘦孔部から消息子 を挿入すると深部では骨様のものに当たるが，下方へは $5 \mathrm{~mm}$ 挿入可能であった. 鼻内所見としては左中鼻道の 狭窄と少量の膿性鼻汁を認めた。後鼻鏡所見では異常を 認めなかった。鼻汁の細菌培養では細菌は認められなか った。また髄膜刺激症状, 脳神経症状は認められなかっ た。

鼻副鼻腔単純 $\mathrm{X}$ 線所見：両側上顎洞特よび篩骨洞に混 濁を認めた。右前頭洞ではその内壁，鼻前頭管部に軽度
の混濁を認めたが著明な変化ではなかった．左側では上 下に長い前頭洞と思われる陰影が認められ，午の上方の 正中部に骨欠損を思わせる病巣所見が認められた。左鼻 前頭管から左前頭洞と思われる部位にかけて混濁を認め た(㘠 1 ).

頭部 CT 所見：前額正中部皮下に軟部組織の腫脹が認 められ，その直上のスライスでは狭小な左前頭洞を示す 所見と，その前壁を構成する骨の一部に欠損像が認めら れた(図 2 )。

頭部 MRI 所見：前額正中やや左寄りに $T_{1}$ 強調画像 でやや低信号から等信号, $\mathrm{T}_{2}$ 強調画像で高信号の部位 を認め, 左前頭洞内での炎症の存在が推定された(図 3 ).

治療経過：以上の所見および検査結果より慢性副鼻腔 炎, 特に左前頭洞炎に起因与る前額部皮下膿瘍と考えら れ，まず平成 3 年 4 月 4 日，局所麻酔下に左上顎洞篩骨 洞根本術を施行した。術中所見では上顎洞粘膜执よび篩 骨洞粘膜は線維性に肥厚し，病理組織検査に扣いては高 度の慢性炎症像を認めた，術中，左中鼻道を前方に向か って十分に開大したが，消息子の鼻内から鼻前頭管への

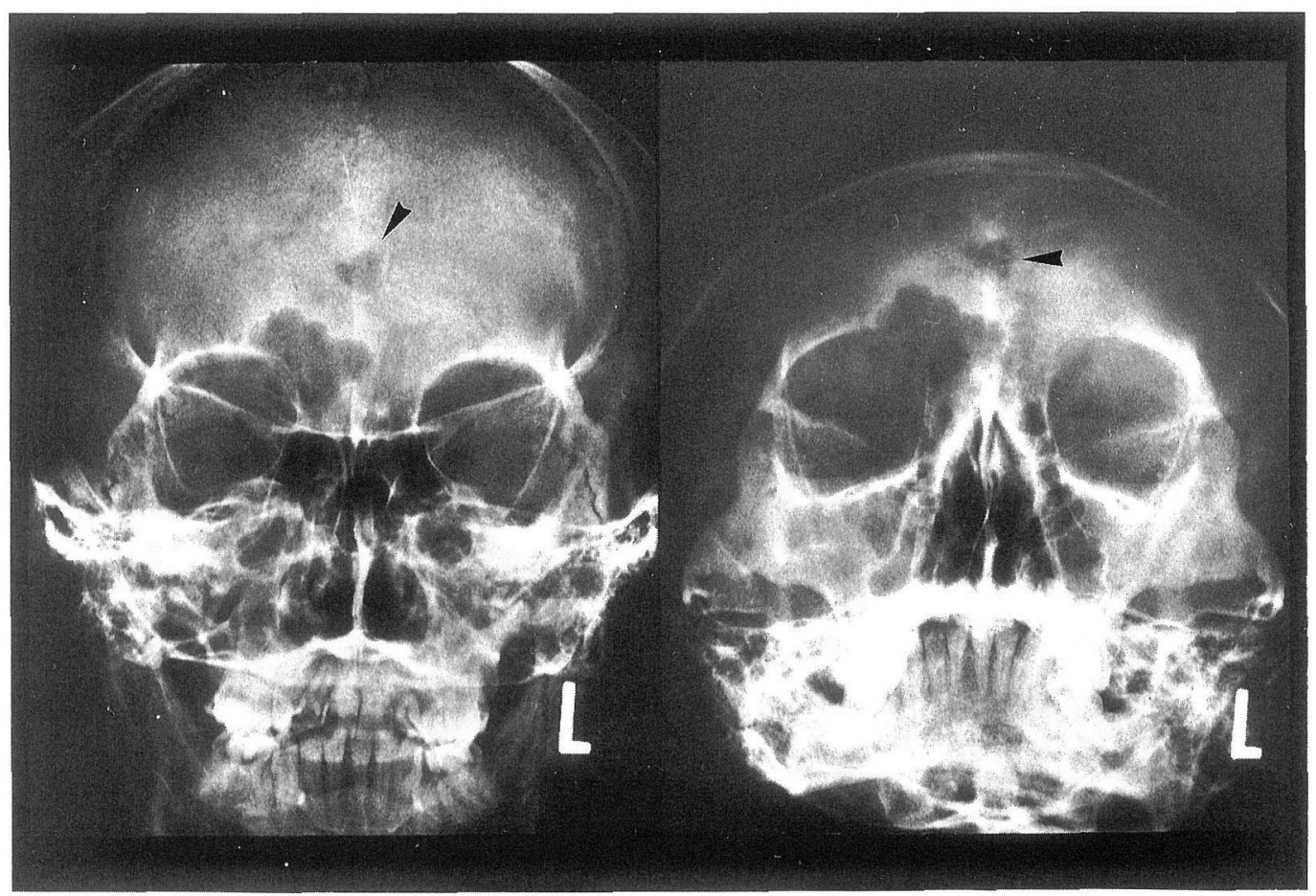

図 1 鼻副鼻腔単純X線撮影

前額部左側に狭小な左前頭洞と推定される陰影を認め, その上方の正中部に骨欠損を思わせる所見 が認められる (知印). 


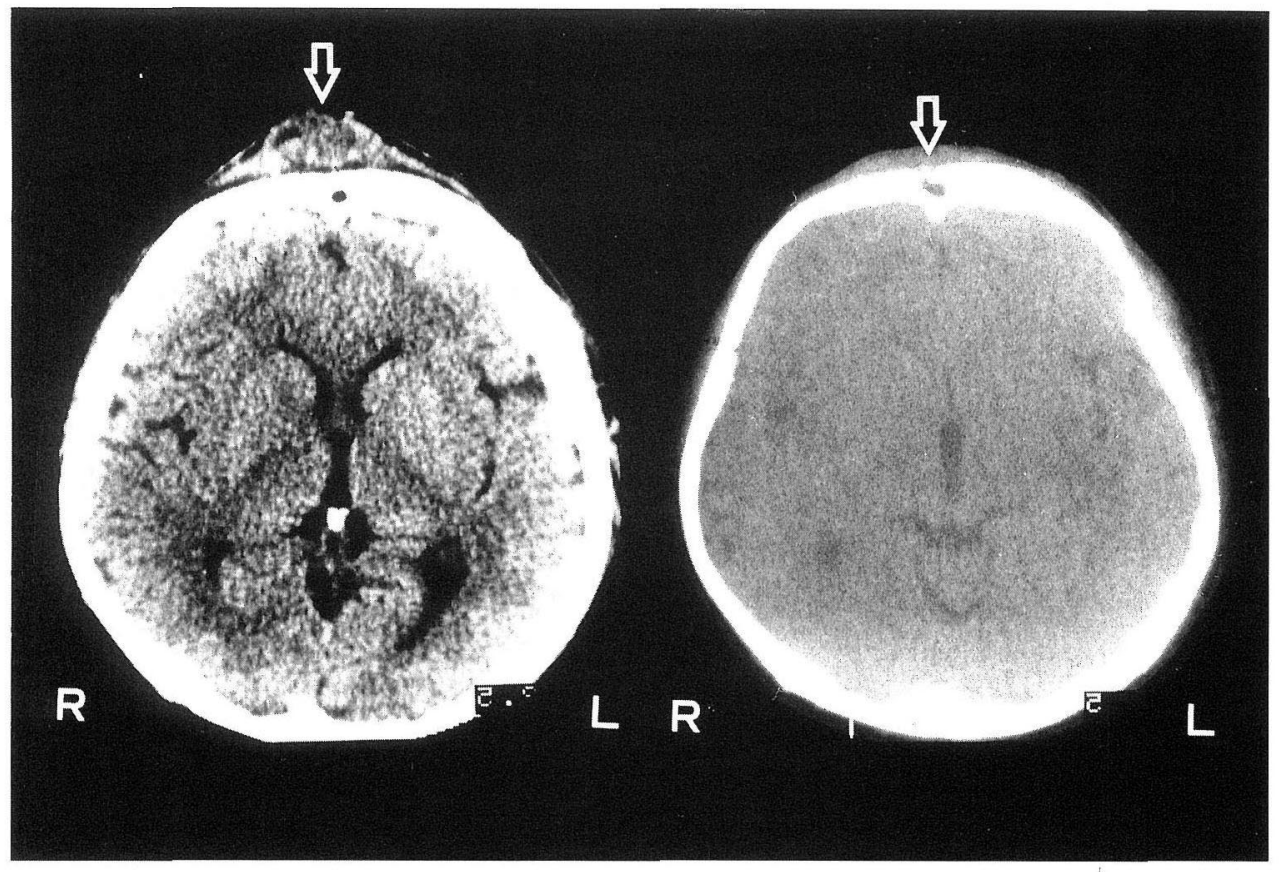

図 2 頭部 CT 像(術前)

前額正中部皮下に軟部組織の腫脹が認められ(左，矢印)，狭小な左前頭洞の存在と，洞前 壁の骨欠損が認められた(右，矢印).

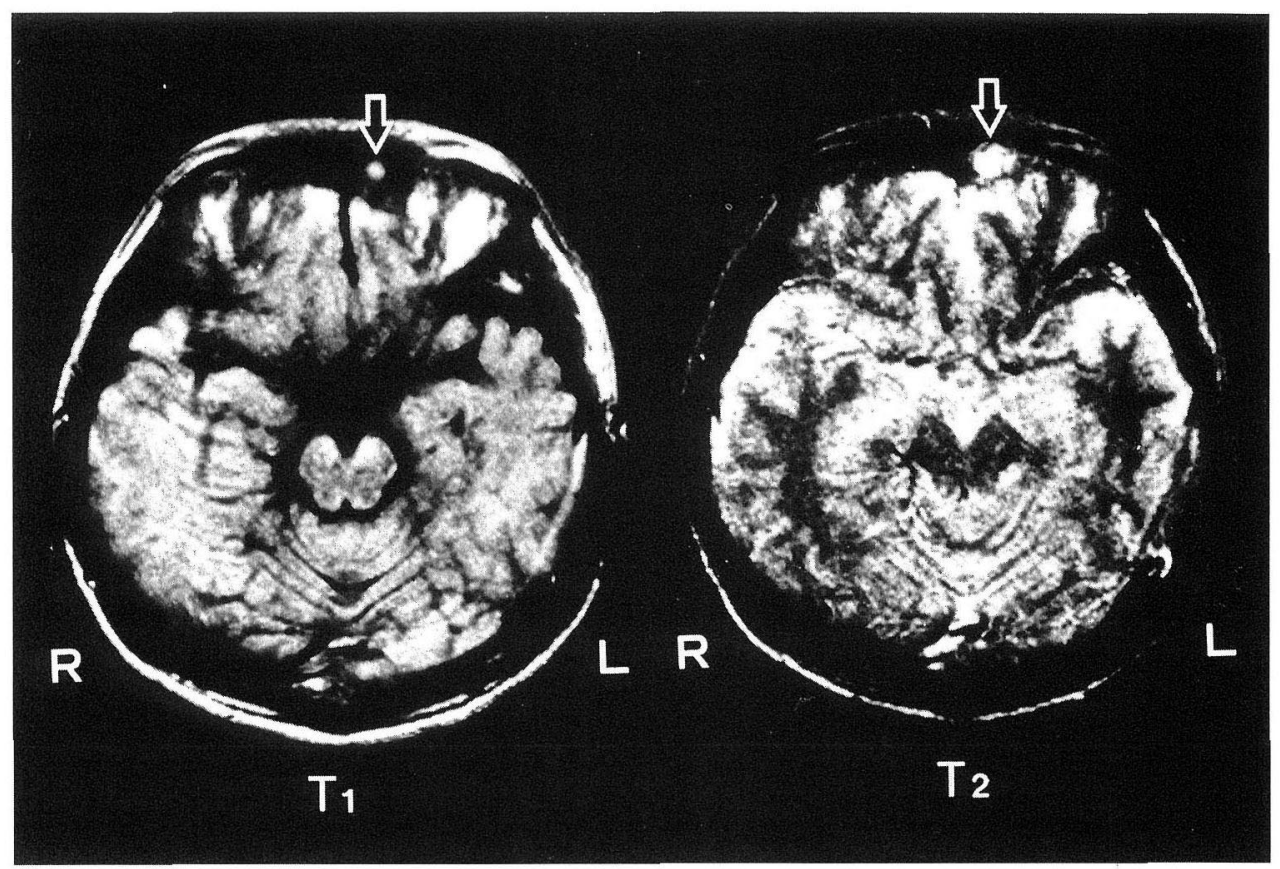

図 3 頭部 MRI

前額正中部に $T_{1}$ 強調画像でやや低信号から等信号, $T_{2}$ 強調画像で高信号の部位が認めら れる(矢印)。 
挿入は不可能であった. 次いで 4 月18日全身麻䣲下に冠 状切開による左前頭洞根本術を施行した.

手術所見：まず前頭部頭髪生它際より約 $3 \mathrm{~cm}$ 後方に 両浅側頭動脈前枝を保存して冠状の皮膚切開線を設定 （図 4 a)，骨膜を保存するようにその直上の層をで㚬開 した後，前額部皮膚执よび筋膜を眼窩上縁まで広範に剝 離し，頭皮を前方に翻転した。皮膚瘦孔部には骨欠損が 存在し(図 $4 \mathrm{~b})$ ，肉芽組織の増生が認められた。その部 分を中心として図 $4 \mathrm{~b}$ のように骨膜切開を加兄，骨面よ り剥離して下方，すなわち眼窩方向へ翻転した。骨欠損
を拡大するよらに周囲の骨をバーにて下方へ削開してい くと, 瘦孔は左前頭洞と推定される狭小な腔に達し，そ こにも肉芽組織の増生が認められた。肉芽を除去しつつ バー，鋭匙を用いて腔内の骨壁を下方に向かって削開， 拡大すると(図 5 ), 左鼻前頭管に達した。鼻前頭管は骨 性に狭小化し，また肉芽組織により閉塞して扣り，バー を用いてこの肉芽組織および骨組織を削開，除去した。 次に自家腸骨より採取した小骨片を用いて鼻前頭管を閉 鎖し，フィブリン糊で間隙を埋めた．左前頭洞および瘦 孔周囲の粘膜病変和よび骨病变を徹底的に除去した後,

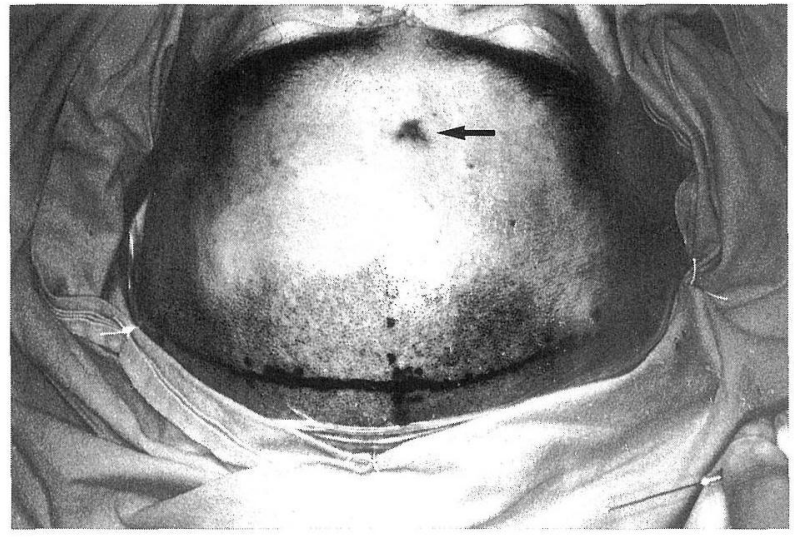

$a$

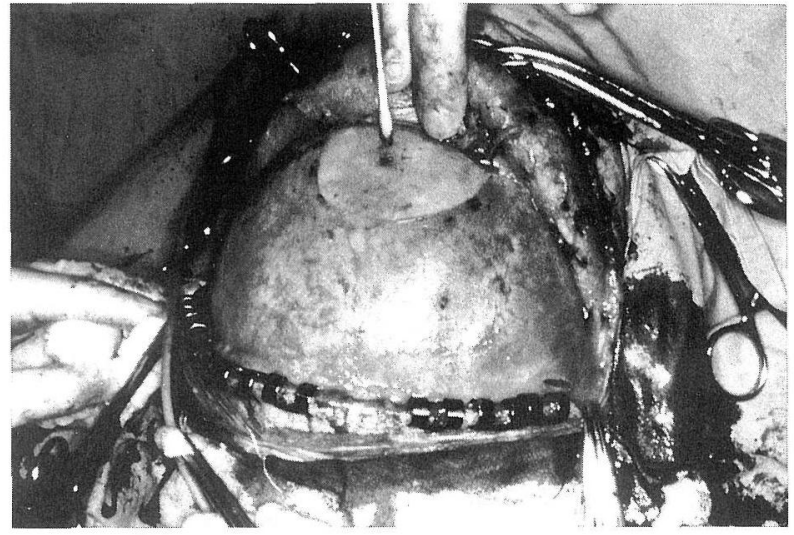

b

図 4 術中所見 1

冠状切開に护ける皮膚切開線を示す．矢印は皮膚瘦孔部位 $(\mathrm{a})$. 頭皮を翻転し骨膜を切開，剝離すると前頭洞前壁に 骨次損が見られ，剝離子先端で示す部位に骨欠損が認められる (b).

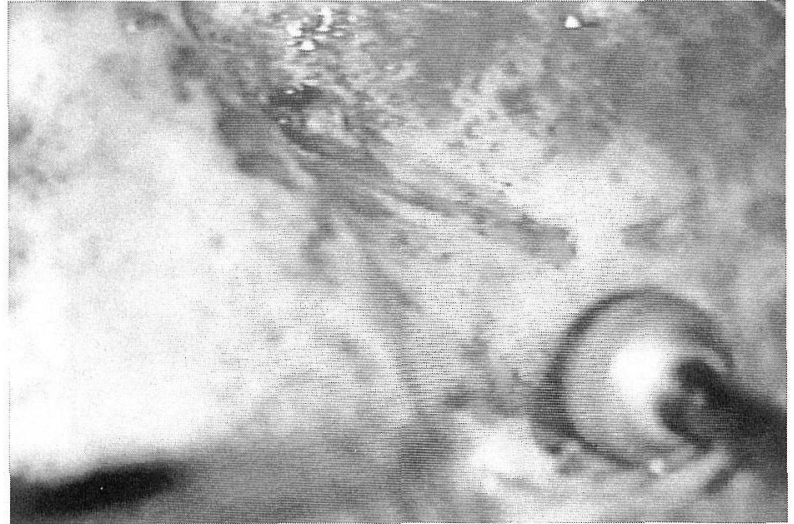

a

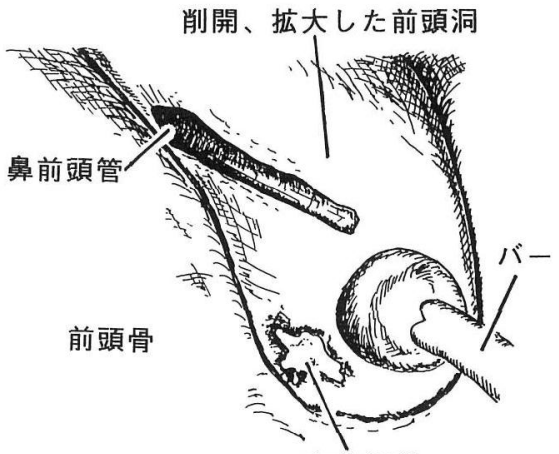

肉芽組織

図 5 術中所見 2

狭小な前頭洞内には肉芽組織が認められた。 


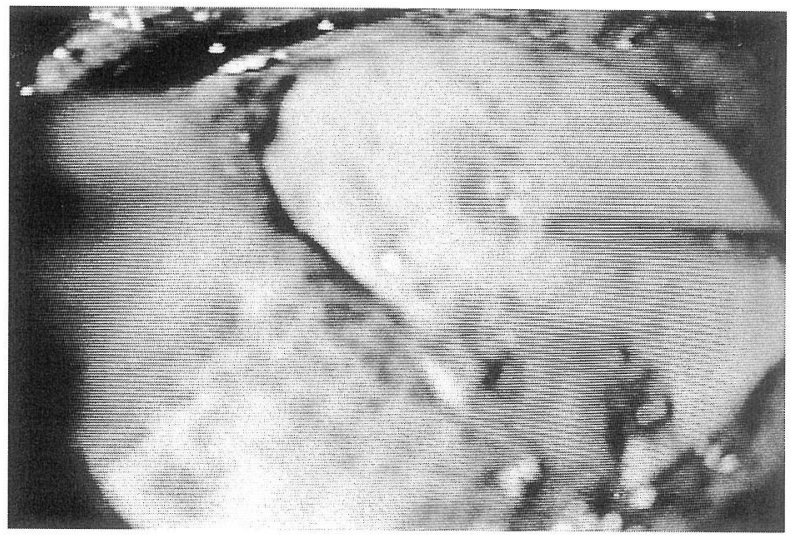

a

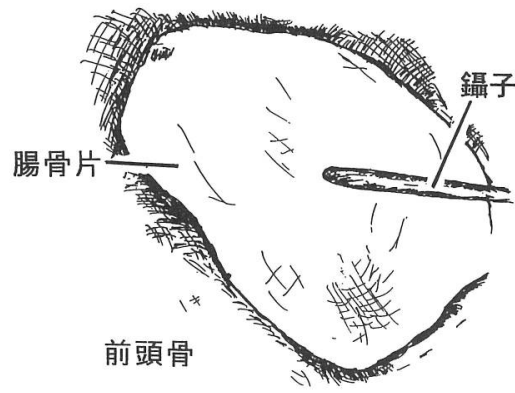

b

図 6 術中所見 3

自家腸骨片を用い前頭洞前壁を再建した。

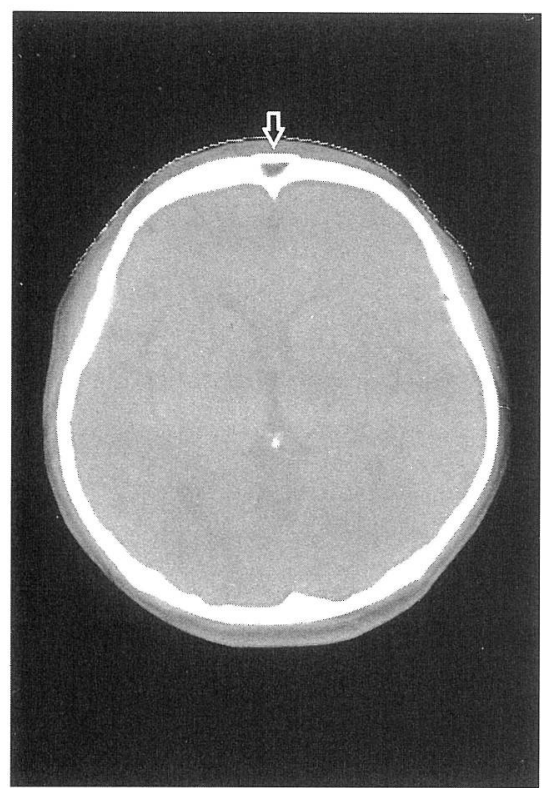

図 7 頭部 CT 像(術後 3 週)

再建した前頭洞前壁が描出される(矢印).

左前頭洞和よび骨欠損部に傍腹直筋脂肪織を充媜した. 前頭部の宿没を防止する目的で自家腸骨片を用いて前頭 洞前壁を形成し(図 6 )，フィブリン糊で骨壁周辺を接着 し，さらに剥離しておいた骨膜を戻し骨膜縫合を行い骨 片を固定した。最後に翻転していた頭皮を戻し，皮膚縫 合を行い手術を終了した。肉芽の病理組織検査では上顎
洞粘膜拉よび篩骨洞粘膜と同様, 高度の慢性炎症像が認 められた。

術後経過：前額部の術後性腫脹や局所感染は認められ ずまた前額部皮膚の運動および知覚障害等も認められ ず，同年 5 月 10 日退院となった. 前額洞根本手術施行後 3 週の頭部 CT 像では再建した前頭洞前壁は明瞭に描出 された(図 7 )。以後現在まで前頭洞炎の再発や前頭部陥 没等の顔面の醜形は来していない。

\section{考按}

前頭洞手術は鼻内法と鼻外法に大別される，前者は明 視下での手術ではその狭い術野ゆ光に洞内粘膜に対する 十分な操作が困難であることがあり, 近年では光学器械 の発達に伴い内視鏡下の手術が盛んに行わ机るようにな ってきた．乙かし一般的には洞内粘膜を明視下に和くこ とが可能な後者が用いられているょうである.鼻外法と しては，キリアン氏法，冠状切開法，骨形成法，骨充媜 法等がある。キリアン氏法は1892年に発表されて以来 その変法も含め, 現在前頭洞手術として本邦では最も頻 回に用いられる術式である。この手術法は皮膚切開が短 く骨削開の範囲が狭いために手術侵襲は少ない。しかし 一方でその皮膚切開は眉毛内弓状切開であることから， 術後顔面に手術創の瘷痕が残ることは避けられず，また 病変が反対側前頭洞に括よぶ症例や骨移植による前壁形 成を必要とする症例では広い術野を確保し難く, 充分か つ安全な手術操作が困難になる。それに比して今回我々 
が用いた冠状切開による前頭洞手術では耳前部上方から 頭頂部にかけて皮膚切開を行い，前額部皮膚を翻転する ことで顔面に手術創般痕を残さず，また前頭骨の広範囲 に招上ぶ病变に対する手術操作も充分に行兄る. 他方, 欠点として皮膚切開が長く, 術野も拡大されているため に, キリアン氏法に比べ出血量が多く, 手術に時間を要 することが挙げられる. Montgomery ${ }^{11}$ は冠状切開によ る前頭洞手術の利点について, 眼窩上神経の障害が起こ らないこと, 術後に顔面の軟部組織の退縮の恐れがない こと等を挙げている．以上のことから前頭洞炎に対する 根治的手術を施行するに際して, 手術操作が広範囲にお よぶ場合, 本症例のように前頭洞の再建を要する場合, 若年女性の症例等顔面に手術創症痕が残ることを避けた い場合等には積極的に冠状切開を用いた術式を選択すべ きであると考兄られる.

前頭洞炎の治癒を確実にし再発を予防するため, 病的 粘膜除去が終了した前頭洞に充填を行らか否か，充堛す るならどのよらな充填物を使用すべきか，また充媜後の 洞内はどの上らな状態に変化していくのかについては未 だ見解の分かれるところである，荻野2) は前頭洞前壁を 用いた骨弁を作製し，前頭洞粘膜を剝離，除去したのち この骨弁を整復する荻野式骨形成手術 (osteoplastische operations methode) を発表している. 前頭洞の充填を 行わないこの方法の術後の治癒機序について荻野は, こ の術式では術後の病的分泌物がなく骨壁に過剩肉芽の発 生原因を与えないが故に健康粘膜の新生が容易となると 述べている. 一方, 前頭洞への充填を行う際, 充填材料 として頻繁に用いられるのが骨扣よび脂肪織である. Goodale ${ }^{3)}$ は以前に自家骨充填による前頭洞手術を受け た症例の前頭洞を観察し, 前回に充媜された骨が反対側 の前頭洞にまで突出している所見を認め, 自家骨充媜は 充填部位に和いて骨新生を促進するのではないかと述べ ている. 田中4)，山下5) はそれぞれイヌの前頭洞に脱蛋 白異種骨を充填する実験を行った. その結果, 術後 1 力 月から 1 年で充填骨の脂肪化から徐々に脂肪䯣が形成さ れるといら知見を得て，これを機能的骨質改変として報 告している. 山下5)による臨床応用では手術を施行した 10 例中 8 例の前頭洞炎が一次的に治癒し，X線撮影では 術後 7 週から 9 週で充填部の陰影は均一化し, 1 年後に は周辺前頭骨とほほ同様の陰影濃度となった。これは前 述した充填骨の機能的骨質改変の可能性を示すものと考 えられ，骨は充媜材料として有用であるとい觉る。
他方, 脂肪織も前頭洞充填資料としてしばしば用いら れている. Goodale ${ }^{3)}$ は腹部脂肪織の充媜を試み, 前頭 洞炎の再発を認めなかった症例の術後 1 年のX線所見か ら, 脂肪織は本来の形で存在し, 充媜した脂肪織は骨新 生を妨げる作用があるのではないかと推測している。ま た Montgomery ら ${ }^{6)}$ は粘膜を除去したネコの前頭洞に 自家脂肪織を充填する実験を行い，それが骨新生を遅ら せ, また感染予防としても機能したと報告している。 Bergara ら7)はイヌを用いた脂肪織充填の実験で, 術後 3 カ月に新鮮自家脂肪織充媜例では洞内の脂肪織は本来 の組織像を呈したが，煮沸自家脂肪織充填例では骨性变 化を来していたと述べている. 今回我々は前頭洞炎を繰 り返した本症例に対して前頭洞内の病的粘膜和よび病的 骨組織を徹底的に除去したのち傍腹直筋脂肪織を充媜し たが，その結果現在まで炎症の再発は認められず，脂肪 織充垻の有用性が改めて認識された。しかし前頭洞炎を 根治せしめるには骨充媜, 脂肪織充媜のいずれが有利で あるかといら結論に至るにはさらに経験を重ねるととも に, 手術症例の長期的な観察が必要であると考兄られる。 前頭洞手術の際, 鼻前頭管を如何に処理すべきかが今 一つの問題となってくる. 現在キリアン氏法拉よびその 変法では再感染時の排泄路として前頭洞と鼻腔の交通路 は必要であるとの見地から，その交通を長期にわたって 確保するため, 術中鼻前頭管にドレーンチューブを留置 し，数日から $2 \sim 3$ 週経過後これを抜去する方法がとら れている．しかし術後経過の中でチューブ抜去後に鼻前 頭管の閉塞を来し，チューブの再挿入が必要であったり， 鼻内上り肉芽を鉗除しなければならないことはしばしば 経験するところである，荻野2) はキリアン変法で手術後， 前頭洞炎が再発した症例を検討し，それらに共通した所 見は病変の遺残と鼻前頭交通路の閉塞であったと述べて いる．また荻野式骨形成手術では術後に鼻前頭交通路の 瘢痕性狭窄を来さないよう鼻前頭管の骨壁は削開しない と述べている2). 荒川 ${ }^{8)}$ は前頭洞への骨充填術を行う際, 再感染時の排泄路に加兄手術時の前篩骨蜂巣の処理の上 で有利な点から，鼻前頭交通路は必要であると述べてい る.

一方で Woods ${ }^{9)}$ は術後の経鼻感染を予防するため鼻 前頭管を充塞することを提唱し，そらすることで治療の 上で前頭洞を 1 つの囊胞として扱うことが可能であると 述べている. Schenck ら 10) はイヌを用いて鼻前頭管を 閉鎖あるいは開存したモデルを作り，それぞれの前頭洞 
飞 Proplast (tetrafluoroethylene carbon fiber) を充填す る実験を行った。その結果，閉鎖群では Proplast 内に コラーゲン線維や新生骨の侵入が認められ，他方，開存 群では Proprast 周囲に強い線維化が認められたが，両 群とも炎症反応は認められなかったと報告している，荻 野2) は先述のように骨形成術では術後の鼻前頭管の開存 を重要視しているが，一方で鼻前頭交通路が骨組織化し て一旦完全に閉塞しても，鼻内から死腔となった前頭洞 への骨組織を介しての炎症の波及は考只られないと述べ ている. 本症例では術前の鼻前頭管は骨性に狭小化して いたら兄に病的肉芽組織により閉塞しており，これらの 病変を完全に除去するためにはバーや鋭匙を用いて鼻前 頭管を削開，拡大しなければならなかった。しかし鼻前 頭管を開放した状態では周囲からの肉芽増生による再狭 窄や経鼻感染の可能性が考兄られたため，鼻前頭管に腸 骨より採取した小骨片を充媜し，さらにフィブリン糊で 間隙を埋めるようにした。先述のように骨充媜は充填部 位に沶いて骨新生を促進すると考兄られ3)，本症例の鼻 前頭管は術後比較的短期間で完全な骨性閉塞を来したも のと考劣られる．このよらに鼻前頭管を骨片を用いて閉 鎖することは，新鮮自家脂肪織による洞内充填の感染予 防機構を促進するものであり, 術後早期の感染や慢性前 頭洞炎の再発の防止といら点で有利であると考光られた。

\section{まとめ}

1. 前額部皮下膿瘍を繰り返した慢性前頭洞炎の症例 に対し冠状切開による根本手術を施行し，良好な結果を 得たので報告し，文献的考察を加えた．

2. 本症例のように広い術野を必要とする前頭骨病変 が存在する場合，冠状切開は有用であると考兄られた。

3. 手術操作として洞内病変を完全に除去後, 骨片に より鼻前頭管を閉鎖し，さらに洞内を腹部脂肪織で充媜 した。そ結果現在まで再発等は認めて抢らず，この手
術方法は前頭洞炎の再発防止に有用であると考兄られた。

本論文の要旨は, 第 31 回日本鼻科学会総会(平成 4 年 10 月, 鈴鹿市)にて口演した。

\section{参考文献}

1) Montgomery WW : Osteoplastic frontal sinus operation; coronal incision. Ann Otol Rhinol Laryngol $74: 822 \sim 830$, 1965.

2 ) 荻野朝一：余の骨形成前頭洞手術法. 耳喉 $28: 968 \sim 980$, 1956.

3 ) Goodale RL : Obliteration of the frontal sinus. Ann Otol Rhinol Laryngol $74: 831 \sim 840,1965$.

4 ）田中一郎：前頭洞充填手術に就いての実験的並びそ臨床的 研究. 耳展 $11: 241 \sim 290,1968$.

5 ）山下建雄 : 前頭洞充填手術法に関する実験的ならびに臨床 的研究. 耳鼻 15 補 $128 \sim 53,1969$.

6 ) Montgomery WW and Pierce DL : Anterior osteoplastic fat obliteration for frontal sinus ; clinical experience and animal studies. Trans Am Acad Ophthalmol Otolaryngol $67: 46 \sim 57,1963$.

7 ) Bergara AR and Itoiz AO : Present state of the surgical treatment of chronic frontal sinusitis. Arch Otolaryngol 61: 616 628, 1955 .

8 ）荒川雄司：前頭洞骨充填手術の実験的並びに臨床的研究. 米子医誌 $13: 341 \sim 372,1962$.

9 ) Woods RR : Operation for chronic frontal sinusitis. AMA Arch Otolaryngol 61 : 54 60, 1955.

10) Schenck NL, Tomlinson MJ and Ridgley CD : Experimental evaluation of a new implant material in frontal sinus obliteration. Arch Otolaryngol 102 : 524 528, 1976.

$$
\left(\begin{array}{l}
\text { 原稿受付: 平成 } 6 \text { 年 } 3 \text { 月 } 7 \text { 日 } \\
\text { 原稿採択 : 平成 } 6 \text { 年 } 9 \text { 月 } 16 \text { 日 } \\
\text { 別刷請求先 : 萩森伸一 } \\
\text { 干 } 569 \text { 高梘市大学町 } 2-7 \\
\text { 大阪医科大学耳鼻咽喉科学教室 }
\end{array}\right)
$$

